\title{
First record of an extinct marabou stork in the Neogene of South America
}

Jorge Ignacio Noriega and Gerardo Cladera

Acta Palaeontologica Polonica 53 (4), 2008: 593-600 doi:http://dx.doi.org/10.4202/app.2008.0404

We describe a new large species of marabou stork, Leptoptilus patagonicus (Ciconiiformes, Ciconiidae, Leptoptilini), from the late Miocene Puerto Madryn Formation, Chubut Province, Argentina. The specimen consists mainly of wing and leg bones, pelvis, sternum, cervical vertebrae, and a few fragments of the skull. We provisionally adopt the traditional systematic scheme of ciconiid tribes. The specimen is referred to the Leptoptilini on the basis of similarities in morphology and intramembral proportions with the extant genera Ephippiorhynchus, Jabiru, and Leptoptilos. The fossil specimen resembles in overall morphology and size the species of Leptoptilos, but also exhibits several exclusive characters of the sternum, humerus, carpometacarpus, tibiotarsus, and pelvis. Additionally, its wing proportions differ from those of any living taxon, providing support to erect a new species. This is the first record of the tribe Leptoptilini in the Tertiary of South America.

Key words: Ciconiidae, Leptoptilos, Miocene, Argentina, South America

J.I. Noriega [cidnoriega@infoaire.com.ar], Laboratorio de Paleontología de Vertebrados, CICYTTP-CONICET, Matteri y España, 3105 Diamante, Argentina; G. Cladera [gcladera@mef.org.ar], Museo Paleontológico Egidio Feruglio, Trelew, Argentina

This is an open-access article distributed under the terms of the Creative Commons Attribution License (for details please see creativecommons.org), which permits unrestricted use, distribution, and reproduction in any medium, provided the original author and source are credited. 
